\title{
LABORATORY EXAMINATION OF CEMENT THICKNESS FOR ZIRCONIA AND COMPOSITE INLAYS CEMENTED WITH TWO TYPES OF FIXING AGENTS
}

\author{
Milena Georgieva-Dimitrova
}

Department of Pediatric Dentistry, Faculty of Dental Medicine, Medical University of Varna

\begin{abstract}
INTRODUCTION: During last decades glass ionomer (GICs) have shown an improvement in handling, less polymerization time, increasing the durability and better wear resistance. Resin composites cements are low viscosity composite materials. They are recommended for cementing ceramic and indirect composite restorations. The zirconia ceramics are not capable of etching for the purposes of cementation with composite fixing agents.
\end{abstract}

AIM: The aim of this article is to make a comparison assessment of the two types fixing agents used for the cementation of indirect aesthetic restorations using zirconium dioxide made via CAD/CAM technology and indirect composite.

MATERIALS AND METHODS: An experimental study of inlays - $\mathbf{6 0}$ made of indirect composite by a technician using the direct-indirect method and 60 made of zirconia ceramics by CAD/CAM technology, was conducted. The inlays were cemented with two types of cementing agents - GIC (Tokuyama Ionotite F) and dual-polymerizing cement (Tokuyama Estecem kit). The unit of observation was the thickness of the cementing agent.

RESULT: There was statistical significant difference $(p<0.05)$ comparing groups, where the thickness of the fixing agent in the zirconia inlays is significantly smaller to the one in composite inlays. This applies to the dual-polymerizing cement (Tokuyama Estecem kit) as well as to GIC (Tokuyama Ionotite F). We could not find any statistically significant difference regarding fixing agent thickness neither in the group of indirect composite inlays nor in the zirconia ones $(p>0.05)$.

CONCLUSION: Both types of cements show satisfying results regarding the thickness of the fixing agent in the four examined groups.

Keywords: restorations, glass ionomer cements, dual-polymerizing cement, CAD/CAM technologies

\author{
Address for correspondence: \\ Milena Georgieva-Dimitrova \\ Faculty of Dental Medicine \\ Medical University of Varna \\ 84 Tzar Osvoboditel Blvd \\ 9000 Varna \\ e-mail:dr.milena.georgieva89@gmail.com
}

Received: April 16, 2019

Accepted: June 27, 2019

\section{INTRODUCTION}

Glass ionomer cements (GICs) have been used as restoration material, bases and cementing agent in the dental medicine since the 1970s (1). Their content is based on polyacrylic acid $(2,3)$. Initially GICs were hard to handle with low durability and brittle as a restorative material. The change of the conventional GICs with resin modified GICs greatly improved their mechanical properties. These products show 
improvement in handling, less polymerization time, increasing the durability and providing better wear resistance.

The resin composites cements are low viscosity composite materials, containing filler and monomer, adapted to create a thin bonding film and proper manipulation time and setting. They have wide spectrum of usage, from inlays to fixed bridges, fiber posts and orthodontic apparatuses. They are recommended for cementing ceramic and indirect composite restorations, but also can be used for cast restorations especially in cases when an additional fixation is needed $(4,5,6,7)$. The clinical efficiency of indirect composite restorations depends on the thickness and the bond of the cement to the hard tooth tissues as well as the inlay $(7,8)$. Zirconia ceramics are not capable of etching for the purposes of cementation with composite fixing agents (9). Zirconia ceramic inlays cemented with self-curing cements show better fracture resistance compared to those cemented with dual-polymerizing cements (10). The polymerizing deficiency of the self-polymerizing component of the dual cements may cause insufficient polymerization of the cement in areas inaccessible to light (4).

\section{AIM}

The aim of the article is to make a comparison assessment of the two types fixing agents used for the cementation of indirect aesthetic restorations from zirconium dioxide made via CAD/CAM technology and indirect composite.

\section{MATERIALS AND METHODS}

The object of the experimental study are 120 cuts of extracted wisdom teeth with 120 inlays -60 made of indirect composite by a technician using the direct-indirect method and 60 made of zirconia ceramics by CAD/CAM technology. The inlays are cemented to standard cavities using two types of cementing agents - GIC (Tokuyama Ionotite F) and dual-polymerizing cement (Tokuyama Estecem kit). The unit of observation is the thickness of the cementing agent. The prepared samples are examined under optic microscope Olympus SZ51 fixed to C-silicone plate. For the analysis of the experimental data parametric and non-parametric statistical methods are used. The study was conducted in the University
Medical Dental Center, Faculty of Dental Medicine at the Medical University- Varna.

\section{RESULTS}

The inlays are divided into four groups - 30 in each group, as the first group includes composite inlays cemented with GIC (1), the second group - composite inlays cemented with dual-polymerizing cement (2), respectively third group - zirconia inlays cemented with GIC (3) and fourth (4) - zirconia inlays cemented with dual-polymerizing cement. Regarding the thickness of the fixing agent we have established that it is highest in the composite inlays cemented with GIC (Group 1) - 0.158mm \pm 0.0262 , followed by Group $2-0.144 \mathrm{~mm} \pm 0.0229$. The smallest is the thickness of the cement used for the fixing of the zirconiazirconia inlays cemented with GIC $0.08 \mathrm{~mm} \pm 0.0206$, and the one in Group 4 is insignificantly thicker- $0.0823 \mathrm{~mm} \pm 0.0237$ (Fig. 1).

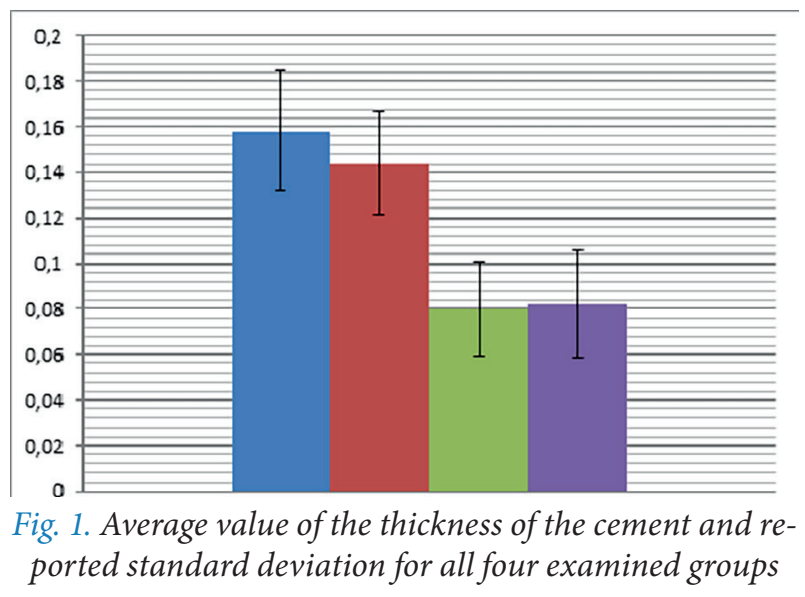

Presented and statistically analyzed, the values of the thickness of the fixing agent show that there is no statistically significant difference between the two groups of composite inlays ( $p>0.05$ ). For Group 1 the lowest value for the cement thickness is $0.12 \mathrm{~mm}$, and the highest one is $0.22 \mathrm{~mm}$. For Group 2 these values are respectively $-0.10 \mathrm{~mm}$ and $0.19 \mathrm{~mm}$. The values for these two groups are with minimal difference $(0.02-0.03 \mathrm{~mm})$. The composite inlays may lose their aesthetic properties as a result of GIC cementation. The adhesive bond with the hard tooth tissues is very important for their retention therefore it is recommended that the fixation be done with dual-polymerizing cements. There is no statistically signif- 
icant difference between the groups of inlays made from zirconia ceramics. In Group 3 the lowest value of the cement thickness is $0.05 \mathrm{~mm}$, and the highest one $-0.13 \mathrm{~mm}$. For Group 4 the values are 0.05 $\mathrm{mm}$ and $0.14 \mathrm{~mm}$, respectively. As the zirconia has only mechanical bond to the hard tooth tissues and is not aesthetically dependent on the fixing agent (has opacity), for the cementation of these inlays GIC is an option of choice. There is statistically significant difference $(\mathrm{p}<0.05)$ comparing all other groups, where the thickness of the fixing agent in the zirconia inlays is significantly smaller than the one in composite inlays. This applies to the dual-polymerizing cement (Tokuyama Estecem kit) as well as the GIC (Tokuyama Ionotite F). During the manufacturing process of zirconia inlays a gap of $0.06 \mathrm{~mm}$ is set in the system software. In regard to this indicator the zirconia inlays show exclusive precision. The better precision of zirconia inlays fixed with both agents is also proved by the smaller thickness of the cementing agent compared to the one in composite inlays $(\mathrm{p}<0.05)$ (Table 1). terval, which varies from 10 (16) to $110.31 \pm 7.22 \mu \mathrm{m}$ (13), more often with results of less than $80 \mu \mathrm{m}$ (11). The internal gap for the cementing agent is between 23.5 $\pm 7.7 \mu \mathrm{m}$ (17) and $154.1 \pm 10.4 \mu \mathrm{m}$ (18).

Study from 2014 compares the microleakage at CAD/CAM made inlays and those made by a technician. The thickness of the fixing agent is bigger in the inlays made by the technician $(84.7 \pm 19 \mu \mathrm{m})$, compared to those made by CAD/CAM technology $(63.4 \pm 16 \mu \mathrm{m})$. No statistically significant difference in microleakage is reported in both groups ( $p>0.05$ ). The microleakage does not correlate with the thickness of the fixing agent, neither in the enamel area, nor in the dentin area. CAD/CAM inlays have a thinner layer of cement, but this has no significance for the microleakage (19).

There are many studies about the properties of GICs, their biocompatibility and cytotoxicity. The use of resin-modified GICs as a fixing agent is getting more popular in the dental practice due to their high mechanical resistance compared with the conventional GICs. They also have fluoride-releasing poten-

Table 1. Thickness of the cementing agent

\begin{tabular}{|c|c|c|c|}
\hline $\begin{array}{l}\text { Indirect composite in- } \\
\text { lays cemented with GIC } \\
\text { (1) }\end{array}$ & $\begin{array}{l}\text { Indirect composite inlays } \\
\text { cemented with dual-po- } \\
\text { lymerizing cement ( } 2 \text { ) }\end{array}$ & $\begin{array}{l}\text { Zirconium inlays ce- } \\
\text { mented with GIC } \\
(3)\end{array}$ & $\begin{array}{l}\text { Zirconium inlays cemented } \\
\text { with dual-polymerizing } \\
\text { cement } \\
\text { (4) }\end{array}$ \\
\hline Mean & Mean & Mean & Mean \\
\hline $0.158333 \mathrm{~mm}$ & $0.144333 \mathrm{~mm}$ & $0.08 \mathrm{~mm}$ & $0.082333 \mathrm{~mm}$ \\
\hline SD & SD & SD & SD \\
\hline $0.026272 \mathrm{~mm}$ & $0.022997 \mathrm{~mm}$ & $0.020678 \mathrm{~mm}$ & $0.023735 \mathrm{~mm}$ \\
\hline
\end{tabular}

\section{DISCUSSION}

The placement of the cement gap is made between the tooth and the restoration and it has significant importance for the precision of the aesthetic construction (11) With a cement gap of $50 \mu \mathrm{m}$, the marginal microleakage is scientifically proven to be lower compared to the one at $100 \mu \mathrm{m}(12,13)$. Two studies which used Cerec 3D show values of the gap for the cementing agent between $135 \pm 35 \mu \mathrm{m}$ and $545.81 \pm 195.8 \mu \mathrm{m}(14,15)$.

Multiple articles report about crowns made of different materials with absolute marginal in- tial. The clinical importance of the GICs is questionable, because the real time for fluoride release is short (20) and the strength of the cohesive bond compared to the one in composite cements is weaker (21). Clinically, the choice of fixing agent depends on the material which the inlay is made of. Inlays made of sintered ceramics (zirconia and aluminium), which are not capable of etching with HF acid, can be cemented with conventional cements, phosphate cement as well as GIC (22). 
In a study from 2014, Boitelle et al. examine the microgap in restorations made by CAD/CAM. They report that the microgap between the tooth surface and the construction is less than $80 \mu \mathrm{m}$, which proves the improvement of the adaptation of CAD/ CAM made restorations compared to the conventional techniques (11). When a cementing method is being chosen dental practitioners have many options for covering the resin-modified GIC, self-adhesive cements or cements with specific adhesive protocol. The attentive dentist conforms the preparation of the hard tooth tissues and the restoration to the retentive properties as well as the thickness of the material. For less retentive preparations (for inlays, onlays etc.) it is recommended for cements with specific adhesive protocol to be used. In such cases the thickness of the material determines whether dual cement will be used or a light cured one. The standard preparations for zirconia constructions can be cemented with adhesive dual cement or GIC $(23,24)$.

\section{CONCLUSION}

The restoration with CAD/CAM made inlays has greatly improved during the last decade. The improvement of the digital impression, software design and the milling technique, as well as the material improvement have led to excellent results. Now every type of ceramic material is capable to restore, fulfilling the requirements of aesthetic dentistry.

Both types of cements (Tokuyama Ionotite F and Estecem Kit) show satisfying results regarding the thickness of the fixing agent in the four examined groups. This is important for the adaptation of the restoration, the retention and microleakage. Dual-polymerizing cement is recommended for high aesthetic constructions - full ceramic inlays and crowns as well as composite ones due the fact that they keep the aesthetic level and provide a great bond with the hard tooth tissues. It relies on the special bonding protocol before the cementation. GIC is recommended for zirconia crowns and inlays, large bridges and metal-ceramic constructions. It provides a great bond with hard tooth tissues and has a fluoride-releasing potential, which is important especially for vital teeth. It is not recommended as a fixing agent for full ceramic as well as composite constructions, because it deteriorates the aesthetic look.

\section{REFERENCES}

1. Wilson AD, Kent BE. A new translucent cement for dentistry. The glass ionomer cement. Br Dent J. 1972;132(4):33-5.

2. McDonald RE, Avery DR, Dean JA. Restorative Dentistry. In: Dean JA, Avery DR, McDonald RE, editors. McDonald and Avery dentistry for the child and adolescent.Mosby; 2008.pp. 322-42.

3. Studen-Pavlovich D, Pinkham JR, Adair SM. The dynamics of change. In: Casamassimo PS, Fields HW Jr., McTigue DJ, Nowak AJ, eds. Pediatric dentistry: infancy through adolescence. 5th ed.St. Louis, Mo.: Elsevier Saunders; 2012.pp.557-617.

4. Darr AH, Jacobsen PH. Conversion of dual cure luting cements. J Oral Rehabil. 1995;22(1):43-7.

5. Federlin M, Krifka S, Herpich M, Hiller KA, Schmalz G. Partial ceramic crowns: influence of ceramic thickness, preparation design and luting material on fracture resistance and marginal integrity in vitro. Oper Dent. 2007;32(3):251-60. doi:10.2341/06-70.

6. Sakaguchi RL, Ferracane J, Powers J. Craig's Restorative Dental Materials. Mosby;2012.pp. 211-51.

7. Latta MA, Barkmeier WW. Bond strength of a resin cement to a cured composite inlay material. J Prosth Dent. 1994; 72(2):189-93.

8. Shortall AC, Baylis RL, Wilson HJ. Composite inlay/luting resin bond strength- surface treatment effects. J Dent. 1996; 24(1-2):129- 35.

9. Giordano R, Sabrosa CE. Zirconia: material background and clinical application. Compend Contin Educ Dent. 2010;31(9):710-5.

10. Sjogren G, Molin M, van Dijken JW. A 10-year prospective evaluation of CAD/CAM-manufactured (Cerec) ceramic inlays cemented with a chemically cured or dual-cured resin composite. Int J Prosthodont. 2004;17(2):241-6.

11. Boitelle P1, Mawussi B, Tapie L, Fromentin O. A systematic review of CAD/CAM fit restoration evaluations. J Oral Rehabil. 2014;41(11):853-74.doi: 10.1111/joor.12205.

12. Al-Rabab'ah MA, Macfarlane TV, McCord JF. Vertical marginal and internal adaptation of all-ceramic copings made by CAD/CAM technology. Eur J Prosthodont Restor Dent. 2008;16(3):109-15.

13. Hmaidouch R, Neumann P, Mueller W-D. Influence of preparation form, luting space setting and cement type on the marginal and internal fit of 
CAD/CAM crown copings. Int J Comput Dent. 2011;14(3):219-26.

14. Aboushelib MN, Elmahy WA, Ghazy MH. Internal adaptation, marginal accuracy and microleakage of a pressable versus a machinable ceramic laminate veneers. J Dent. 2012;40(8):670-7. doi: 10.1016/j. jdent.2012.04.019.

15. Estafan D, Dussetschleger F, Agosta C, Reich S. Scanning electron microscope evaluation of CEREC II and CEREC III inlays. Gen Dent. 2003;51(5):450-4.

16. Rungruanganunt $P$, Kelly JR, Adams DJ. Two imaging techniques for $3 \mathrm{D}$ quantification of precementation space for CAD/CAM crowns. J Dent. 2010;38(12):995-1000. doi: 10.1016/j. jdent.2010.08.015.

17. Bindl A, Mormann WH. Fit of all-ceramic posterior fixed $€$ partial denture frameworks in vitro. Int $J$ Periodontics Restorative Dent. 2007;27(6):567-75.

18. Son $\mathrm{Y}-\mathrm{H}, \mathrm{Han} \mathrm{C}-\mathrm{H}, \mathrm{Kim} \mathrm{S}$. Influence of internal-gap width and cement type on the retentive force of zirconia copings in pullout testing. J Dent. 2012;40(10):866-72. doi: 10.1016/j.jdent.2012.07.007.

19. Alaghemand H, Abolghasemzadeh F, Pakdel F, Judi Chelan R. Comparison of microleakage and thickness of resin cement in ceramic inlays with various temperatures. J Dent Res Dent Clin Dent Prospects. 2014;8(1):45-50. doi: 10.5681/joddd.2014.008.
20. Friedl KH, Schmalz G, Miller KA, Shams M. Resin-modified glass ionomer cements: fluoride release and influence on Streptococcus mutans growth. Eur J Oral Sci. 1997;105(1):81-5.

21. Van Dijken JWV, Örmin A, Olofsson AL. Clinical performance of pressed inlays luted with resin-modified glass ionomer and autopolymerizing resin composite cements. J Prosthet Dent. 1999;82(5):529-35. doi: 10.1016/ s0022-3913(99)70051-x.

22. Hopp CD, Land MF. Considerations for ceramic inlays in posterior teeth: a review. Clin Cosmet Investig Dent. 2013;5:21-32. doi: 10.2147/CCIDE. S42016.

23. Bielen V, Inokoshi M, Munck JD, Zhang F, Vanmeensel K, Minakuchi S, et al. Bonding effectiveness to differently sandblasted dental zirconia. J Adhes Dent. 2015;17:235-42. doi: 10.3290/j.jad. a34401.

24. Vallée J, Noble WH, Gupta S, Schulze KA, Hakim F. Selection guidelines for all-ceramic restorations. Decis Dent. 2017;3(3):24-8. 